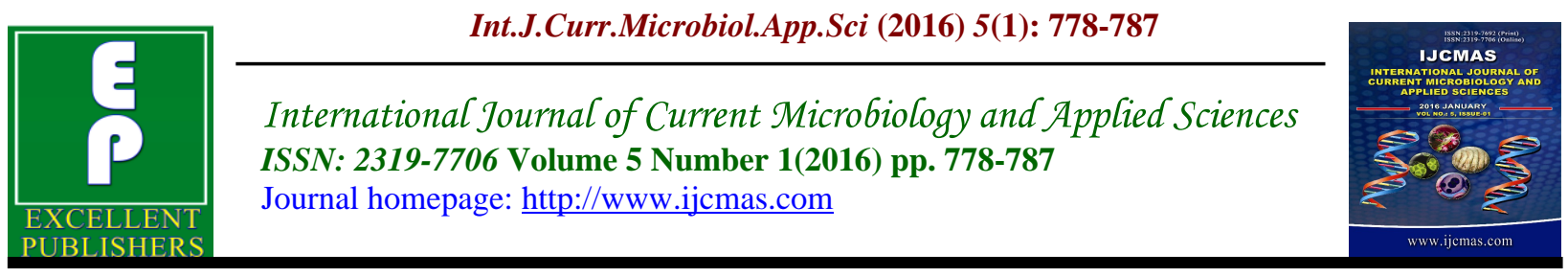

Original Research Article

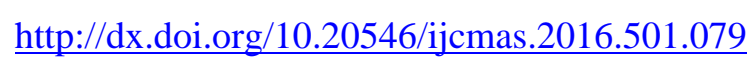

\title{
Genetic Diversity and Relationships among Mango Varieties using RAPD Molecular Markers
}

\author{
R. Pruthvish ${ }^{1}$ and B.K.Chikkaswamy ${ }^{2 *}$ \\ ${ }^{1}$ Department of Biotechnology, Acharya Institute of Technology, Soladevanahalli \\ Hesaraghatta Road, Bangalore, India \\ ${ }^{2}$ Sigma BioScience Research Center, Indira Nagar Bangalore-560038, India
}

*Corresponding author

\begin{tabular}{|c|c|}
\hline & A B S T R A \\
\hline & \multirow{4}{*}{$\begin{array}{l}\text { Mango is the genus of tree \& bushy tree in the family Mangnoliaceae. Most of the } \\
\text { Mango varieties are dioceous and cross-pollinate to produce to produce fertile } \\
\text { hybrids suggesting a closer genetic relationship which is not expected at species } \\
\text { level. The traditional methods using morphological characters are not successful in } \\
\text { establishing the diversity and relationship among } 19 \text { different Mango varieties } \\
\text { because of the environmental influence.PCR based molecular marker method, } \\
\text { RAPD was employed to study the genetic diversity and Inter-relationship among } \\
19 \text { Mango varieties. On an average RAPD analysis generated 5-6 discrete bands/ } \\
\text { varieties with } 10 \text { nucleotides primers. The size of the amplified products ranged } \\
\text { from } 100-3500 \text { base pairs in length. With an average of 5-10 bands per primer. Of } \\
21 \text { amplified fragments } 50 \text { were polymorphic ( } 80 \%) \text { with at least one pair wise } \\
\text { comparison between } 19 \text { varieties. RAPD analysis identified varieties specific } \\
\text { amplification products which will be useful in germplasm classification and } \\
\text { introgression studies. These results indicated that RAPD based markers are useful } \\
\text { for genetic characterization of Mango/varieties/accessions. }\end{array}$} \\
\hline $\begin{array}{l}1 \\
\text { N }\end{array}$ & \\
\hline & \\
\hline & \\
\hline
\end{tabular}

\section{Introduction}

Genetic fingerprinting has been accomplished traditionally through the use of isozymes, and more recently through reactions fragment length polymorphisms (RELPs), variable number tandem repeats (VNTRs), or a combination of these. While these methods have been very useful in cultivar identification, they have a number of disadvantages, including a limited number of isozyme loci, and the time, expense, and use of (32 $\quad$ P) for labeling with RELPs and VNTRs. Polymerase Chain Reaction (RAPD) uses arbitrary 10-base primers to amplify randow portions of the genome (Welsh and McCIelland 1990; Williams et al. 1990).The fragments produced are easily visualized on an ethidium bromide stained gel, and polymorphisms between genotypes reflect heritable differences in the genome. Large 
numbers of bands, or loci, can be generated with relative ease. Due to the arbitrary nature of the primers, RAPD markers, unlike RELPs, VNTRs, and isozymes, represent a random sample from the entire genome. They are, however, inherited as dominant markers, requiring larger numbers of loci to be identified and screened to glean the same information as from RELPLs, VNTRs, and isozymes. Amplification of bands in the progeny which were not amplified in either parent has also been reported (Riedy et al. 1992).

The use of RAPDs to determine genetic relationships has been demonstrated in maize (Welsh et al. 1991), conifers (Carlson et al. 1991), caca (Wide et al. 1992), and various leguminous pecies (Charlmers et al. 1992, Echt et, al.1992). Within Mangifera (mango) species RAPDs have been used to determine phylogenetic relationships (Schnell and Knight 1993). On the basis of the classification of Kostermans and Bom.

RAPD fingerprinting techniques have been used for the identification of horticultural crop varieties, description of cultivars genotypes and for protecting breeder's rights (Williams et al., 1990) enabling assay to be performed at any stage of plant development. RAPD markers have been extensively used to distinguish intraspecific genetic variation in ornamental crops and detection of hybrids and clones (Collins et al., 2003; Arus, 2000; Debener, 2001a).

Ranamukhaarachchi et al. (2001) showed that RAPD markers had the ability to identify pot-plant mango cultivars is crucial to local breeders involved in hybridization programs for varietal development but is currently lacking. In this study, RAPD markers were used to evaluate the extent of genetic variation among some mango cut flower cultivars.
Until recently, several promising species released formally are characterized on the basis of morphological data, mango content and yield potential. Worldwide demands on mango necessitate work on conservation of mango germplasm and their further genetic improvement. Therefore precise characterization of promising species and determination of genetic variation among those are felt necessary.

Until recently, several promising species released formally are characterized on the basis of morphological data, mango content and yield potential. These characters differ under varying environmental condition thereby posing problem identification of species. Unlike morphological markers, cytological (chromosome numbers, nuclear DNA content) and molecular markers (RAPD, AFLP, ISSR etc.) are not prone to environmental influences and characterize the plants portraying the extent of genetic diversity among taxa (Bennett 1987,Bennett and Smith 1991,Waugh and Powell 1992,Chalmers et al.1994, Das et al.1998, Rodriguez et al.1999, Das et al.2001).

Of the different markers, RAPD has been widely used in the last decade in species identification programmed (Schnell et al.1995) and in assessing genetic variations among different taxa at DNA level because of its cost effectiveness and simple operation without requiring prior knowledge of species DNA sequences (Williams et al.1990, Frankel et al.1995). RAPDs reveal similar patterns of genetic diversity when compared with other marker types and can be performed more rapidly than most other methods (Morell et al.1995) and can provide vital information for the development of genetic sampling, conservation and improvement strategies (Waugh and Powell 1992, Chalmers et al.1994). No report has been published so far either on the genetic 
characterization or on the extent of genetic variations existing among promising species of mango.

The present study deals with the in situ DNA estimation and RAPD analysis of 19 promising species of Mango to identify and evaluate extent of genetic variation existing among these.

As the efficiency of selection scheme or genetic analysis based on phenotype is a function of heritability of the trait, factors like environment, traits of mutagenic and quantitative inheritance or partial and complete dominance often confound the expression of genetic traits. Many of these complications of a phenotype-based assay can be overcome through direct identification of species with DNA based diagnostic assay. For this reason DNA based genetic markers are being integrated into several plant systems under expected to play an important role in the future plant improvement programmes.

Advent of Polymerase chain reaction (PCR) technology as lead to the development of several novel genetic assays based on selective DNA amplification Krawetz (1989) and Innis et al (1990). RAPD assay detects nucleotides sequence of polymorphism in DNA using only a single primer of arbitrary nucleotide sequence. The protocol is also relatively quick and easy to perform and uses fluorescence instead of radioactivity. Because the RAPD technique is amplification- based assay, only nanogram quantity of DNA is required. One of the strengths of these new assays is that they are more amenable to automation than conventional techniques. It is simple to perform and is preferable to experiment; their species of large number of individuals are to be determined at a few genetic loci.The present investigation will be carried out on RAPD molecular marker studies in varieties of mango plants with the following objectives. To develop protocol for isolation of DNA from different 19 varieties of mango plants. To develop PCR protocol and to identify RAPD markers to score in various mango plants. To assess the genetic diversity and relationships among mango plants using RAPD molecular markers belonging to family magnoliace.

Matias Kirst et.al.,(2004) studied on DNA marker RAPD,RFLPs and AFLP etc in forest tree species and in particular its application to tree breeding and tree genomics.

Million and Chinnappa (2000) assessed the genetic divergence in forty seven genotypes of

Stellaria longipes (Caryophyllaceae) using RAPD analysis. Datta and Mitrick et.al.,(1997) studied the classification of common bean Phaseolus vulgaris from Chile using RAPD data.The study reveals that 95 bean accessions analysed using 25 primers that generated 106 polymorphic bands of RAPD collected from different locations.

Nirupama et.al., (2003). Reported genetic diversity and relationship of 51 accessions of Vetiver using RAPD/AFLP analysis.Total of 20 primers were used to generate 5 clusters using UPGMA cluster analysis where as for AFLP analysis nine primers are used to generate 383 unique bands specific to different accessions compared 81 monomorphic bands.In contrast sufficient diversity existing with in the wild and cultivated.Indian germplasm. Raghvendra saxena and Amaresh Sanghamitra Nayak et.al. (2006) studied the 4C nuclear DNA content and RAPD analysis of 17 promising cultivars of turmeric Curcuma longa of 
zingiberaceae is an important spice and anticancer properties and also showing differential genetic variation among cultivars. The polymorphism ranged from $35.6 \%$ to $98.6 \%$.

Schnell et.al.,(1995) studied the identification of cultivars and genetic relationships in Mangifera indica using RAPD technique. 25 accessions of mango were examined using 80 primers. Of the 80 primers 33 did not get amplified 19 were monomorphic and 28 gave

\section{Materials and Methods}

The present study selected leaf samples of the 19 mango plants plants that were collected from the conservatory of Biotechnology Centre, Hulimavu, Department of Horticulture, Bangalore, Karnataka, India. Which may represent the wide variation prevalent in the genome The recently matured leaves were collected and used for DNA extraction.

Porbeski et al. (1997) described a relatively quick, inexpensive and consistent protocol for extraction of DNA from expanded leaf material containing large quantities of polyphenols, tannins and polysaccharides. Mature strawberry leaves, which contain high levels of the secondary components, were used as a study group. The method involved a modified CTAB extraction, employing high salt concentrations to remove polysaccharides, the use of polyvinyl pyrrolidone (PVP) to remove phenols, an extended RNAse treatment and phenol-chloroform extraction. Average yields ranged from $20-84 \mu \mathrm{g} / \mathrm{g}$, mature leaf tissue for both wild and cultivated octoploid and diploid Mango. Results from 19 plants were examined and were consistently amplifiable in the RAPD reaction with as little as $0.5 n$ DNA per $25 \mu$ reaction. Presently this is the first procedure for the isolation of DNA from mature strawberry leaf tissue that produces consistent results for a variety of different species, both octoploid and diploid, and is both stable and PCR amplifiable before and after extended storage.

\section{Quantification of DNA}

DNA quantification can be done by flurometry, spectrometry and agarose gel electrophoresis with standard DNA concentrations (Boiteux et al., 1999). The quality can be assessed by restriction digestion with restriction endonucleases (EcoRI, HindIII etc.,) electroporation and spectral properties. Quality is that to what extent the DNA is pure of secondary metabolites and other substances, which hinder further use of DNA in molecular techniques. A good DNA preparation generally exhibits the following spectral properties. It will have $\mathrm{A}_{230}, \mathrm{~A}_{230} / \mathrm{A}_{260}$, $\mathrm{A}_{280} / \mathrm{A}_{260}$ or $\mathrm{A}_{260} / \mathrm{A}_{280}$ rations of less than 0.10 , less than 0.45 , less than 1.65 or more than 1.80, respectively (Shantha et al., 1998). If a DNA preparation exhibits $\mathrm{A}_{260} / \mathrm{A}_{280}$ more than 1.80 , it shows the presence of RNA and if it is less than 1.65 or less indicates protein contamination (Sambrook et al., 1989).

\section{Results and Discussion}

The data obtained in the present study regarding RAPD Molecular Marker studies in 19 Mango varieties The present study reveals that RAPDmarkers are good choice for assessing the genetic diversityand relationship in Mango varieties with polymorphism levels enough to establish informative fingerprints with a few markers. The information obtained could be of practical use for mapping the mulberry genome as well as for classical breeding. The study also provides a closer basis for 
mango breeders to make informative choice on selection of parental materials based on genetic diversity and overcome the problem usually associated with mango crop improvement. The important primers identified will be useful for molecular characterization of gene bank accessions.

19 collections of Mango varieties (Alphonso, Bangalora, Mulgoa, Neelum, Pairi, Banganapalli, Bombay, Bombay Green, Chausa, Dashehari, Fazli, Fernandian, Himsagar, Kesar, Kishen Bhog, Langra, Mallika, Mankurad, Totapuri) which are distributed in different regions Bangalore, are from diverse origin and possibly represent the genetic diversity existing in the species table 1 OPD 1-12.

The RAPD analysis: The random primers amplified with genomic DNA of different Mango varieties generated 55 RAPD bands in the size ranged from 1000 base pairs in length. The number of bands obtained per primer ranged from 5-6 with an average of 11 with exception in some of the lanes where no amplification and bands formation has not taken place was observed. A total of $80 \%$ bands was polymorphic. The complete amplification details are presented in the table 2. DNA profiles generated by OPD 112 are shown in fig 1

The genetic analysis of RAPD markers based on Ward's method of Euclidean distance showed genetic similarity among the collection of Mango varieties Fig 2.The collection of Alphonso \& Bangalora was closest with the maximum similarity $(95 \%)$ whereas Mulgoa and Neelum forms separate cluster than other varieties. Euclidean Ward's method clustering based on RAPD data showed clear separation of collections fig 2. Some of the Mango varieties are available abundantly with in 19 Mango species even though a few species of Mango occur naturally in India and Karnataka many cultivated species of Mango varieties do not find their origin outside the country of some of the cultivated Mango accessions which are classified as different species, cross pollinate with each other and produced fertile offspring showing no signs of sexual incompatibility characteristics of species. This fact suggests a close genetic relationship among the cultivated Mango species. The present investigation involving 19 Mango varieties and its RAPD analysis further supports this view.

The high level of polymorphism $(80 \%)$ in Mango varieties reflects out crossing nature on par with results obtained with RAPD in other fruits and nut tree species such as Pistachio (Hormaza 1995),olive (Fabbri et.al.,1995),walnut (Nieise et.al.,1998) and vegetatively propagated crop such as banana (Krammer et.al.,1992) and apple (Koller et.al.,1993).Similar results was reported by Schnell et.al., (1995) Karinaloo et.al., (2003) \& Maria cristina et.al., (2006). The molecular analysis using RAPD markers did not show corelation between the ploidy and number of polymorphic bands suggesting the redundancy of genome complements in these species. The ploidy level of a plant does not appear to influence the number of fragments per primer (Wolf and Peter Vanrijn 1993).In Mango varieties percentage of similarity based on $\mathrm{F}$ value ranged 80 to 30 most of the Mango pairs had shown similarity value some of the morphological variation and improvement in agronomic traits, leaf yield have been achieved through selective cultivation and breeding programmes, there appears to be effort has been made to utilise the useful trait found in Mango varieties. 
Fig.1 Gel Diagram of Mango Using Opd 1-12 for 19 Mango Varieties

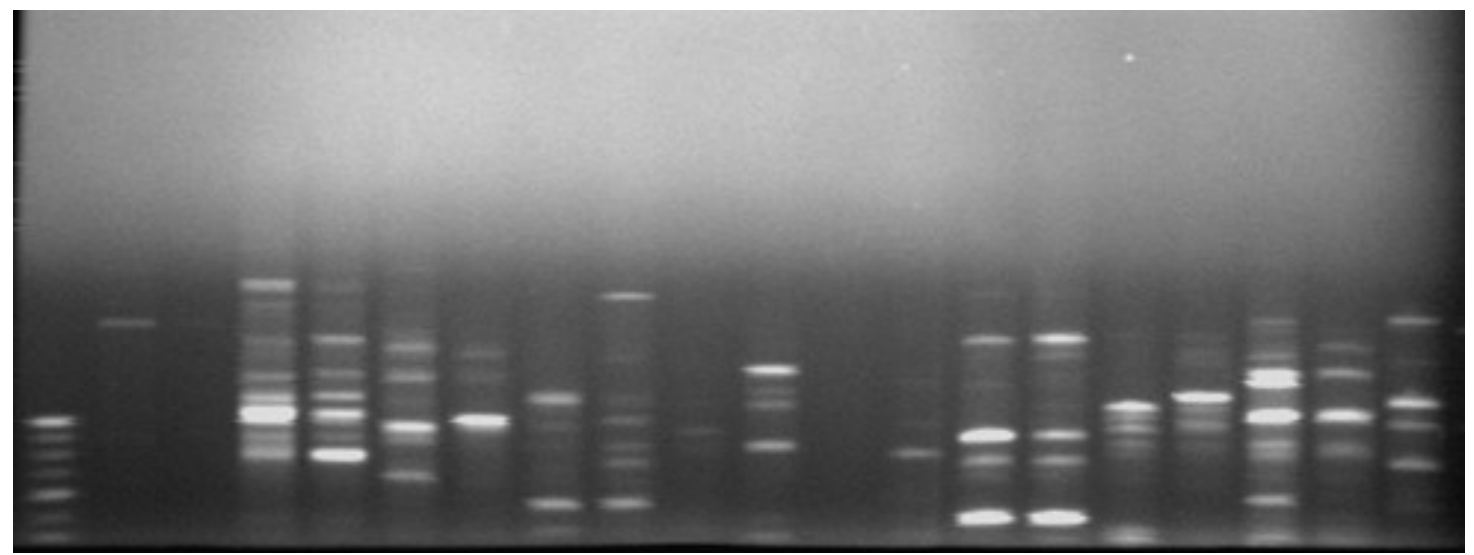

Tree Diagram for 19 Variables

Single Linkage

Euclidean distances

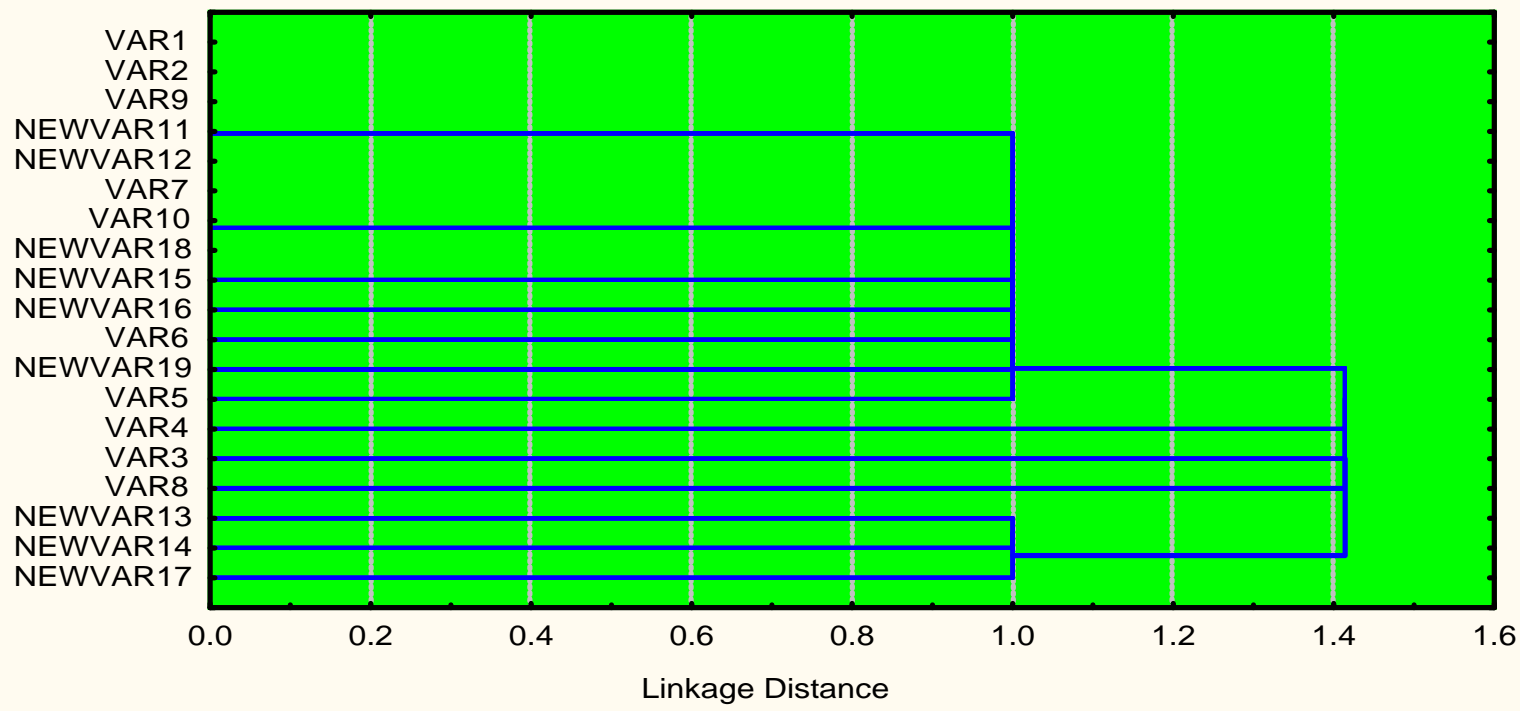

The present study has made an attempt to assess the genetic diversity among 10 collection from different region of Bangalore. Morphological traits are greatly influenced by the environment. It has always been difficult to accurately assess the diversity and interrelationship among Mango varieties similar report was reported by (Awasthi et al., 2004) on mulberry plant. DNA marker such as RAPD and ISSR have become a handy tool for quick and reliable estimation of diversity for crop improvement and conservation programme in mulberry (Sharma et al., 2000).

The present results also showed number of RAPD bands such as 2,2,0,20,4,4,2,2,46 respectively in Mango varieties, Mango 1 and Mango 2 further Ward's method of genetic distance bu Squared Eucleidean distances dendrogram revealed maximum similarity between Alphonso \& Bangalora Whereas Mulgoa and Neelum forms separate cluster than other varieties. 
The mean genetic similarity was less in the case of Mango officinalis and Mango malabaricum indicating a diverse genetic background of the former. This conclusion is also supported by the large variabilty exhibited in phenotypic traits reported by Ravindran et al., 1997 in mulberry plants. The RAPD data separated the varieties in to three distinct group confirming their taxonomic status unambiguously which are geographically isolated and thriving in comparatively different habit. Due to high heterozygosity of the species it is not possible to conserve the seeds unresisting condition and is maintained in the vegetative form in the field gene bank. Most of the primers used for DNA profiling of the Jamine collections generated polymorphisms.

The present study gives an instinct into the broad genetic structure of this varieties. The information generated from the study will be useful for further in depth analysis of these varieties towards utilization in Mango improvement and conservation programmed.

\section{References}

Ajibade S.R., Weeden.N.F \& Chite S.M., Inter simple sequence repeat analysis of genetic relationship in the genus Vigna.Euphytica 111:47-55. (2000).

Ajit K.Shasany, Alka Srivastava, Janak R.Genetic diversity assessment of Mentha spicata L.germplasm through RAPD analysis fifteen elite accessions in the national gene bank of Mentha spicta L.IPGRI Plant Genetic Resources Newsletter Portal.130, 1-5, (2002).

Akagi, H.; Yokozeki, Y.; INagaki, A and Fugimura, T. (1997) highly polymorphic microsatellites of rice consist of AT repeats and a classification of closely related cultivars with these microsatellite loci.
Theor.Appl.Genet., 94 61-67.

Akagi, H.; Yokozeki, Y.; Inagaki, A.; Nakumura, A.and Fujimura, T. (1996) A codominant DNA marker closely linked to the rice nuclear restorer gene, RF-1, identified with inter -SSR fingerprinting.Genome, 39:1205-1209.

Akito Kaga,Norihiko Tomooka,Yoshinobu Egawa, Kazuyoshi Hosaka \& Osamu Kamijima.Species relationships in the subgenus Ceratotropis (genus Vigna) as revealed by RAPD analysis. Euphytica 88:17-24.1996.

Akkaya, M.S., Shoemaker, R.C., Specht, J.E., Bhagwat, A.A., and Cregan, P.B. (1995).Integration of simple sequence repeat DNA markers into a soybean linkage map. Crop Sci.35:1439-1445.

Alstrom-Rapaport, C., Lascoux, M.,-Wang, Y.C., Roberts, G.and Tuskan, G.A, (1998), Identification of RAPD marker linked to sex determination in basket willow (salix viminalis L.). J. Heredity, 89 (1):44-49.

Antoni rafalski, scott tingey and john g.k.williams.1994.Random amplified polymorphic DNA (RAPD) markers.Plant Molecular Biology Manual.H4:1-8.

Armour. R.P. (1959), (Investigations on Simarouba glauca DC in E1 Salvador.) Eco. Bot., 13:41-66

Arumuganathan, and Earle, D, (1991). Nuclear DNA content of some important plant species Pant.Mol.Bio Rep., 9(3):208-218.

Arus P,Shields C.R,Orton J J (1985) Application of isozyme electrophoresis for purity testing and cultivar identification of F1 hybrids in Brassica oleracea. Euphytica 34:651-657.

Atal.C.K., (1959), (Sex reversal in hemp by application of gibberelin.) Curr.Sci.28:408-409

Ausubel.M.F, Brent.R.Kinton.E.R. Moore. D. D. Smith.A.S.and Struhl.K, (1989), 
preparation and analysis of DNA In; current protocols in molecular biology. johnwily and sons, Inc Newyork chapter2,section 1,pp.435-460

Awasthi,A.K.;Nagaraja,G.M.;Naik,V.G;Kan ginakudru,S.;Thangavelu,K. and Nagaraju,J.(2004).Genetic diversity and relationships in mulberry (genus Morus) as revealed by RAPD and ISSR marker assays.BMC Genetics, 5:1-9.

Bagchi G.D,Jain D.C and Sushil Kumar.1998.The Phytotoxic effects of the artemisinin related compounds of Artemisia annua.Journal of Medicinal and Aromatic Plant Sciences 20.5-11.

Banerjee, N.S., Manoj, P. and Das, M.R., (1999), male sex associated RAPD markers in longum l. Curr. 77 (5): 693695.

Bartolozzi.F. Warburton.M, L., Arulsekar. S. and Grad Ziel.T.M., (1998). Genetic Characterization and Relatedness among California Almond Cultivars and Breeding lines detected by RAPD analysis J. Amer. Soc. Hort. Sci., 123(3): 381-387

Baudraco, A.S, and Pittrat, A, (1996), Agenitic map of melon (Gerenmos melo L.)With RAPD, RFLP, Isozyme, disease resistance and morphological markers, Theor Appl.Genet, 93; 57-64

Bauforth, K.R.N, Nelson, P.N, Digby, J.E.Neil,.J.D.O and Murry, P.G, (1999), polymerase chain reaction.mol.pathol. $52 ; 1-10$

Baumforth, K.R.N, Nelson, Digby, J.E. Neil, J, D.O and Murry, P.G, (1999), polymerase chain reaction. mol. pathol., $52 ; 1-10$

Bawa. K.S., (1980), Evolution of dioecy in flowering plants. Annu.Rev. Ecol. Syst. 11:15-39

Bawa. K.S., (1980), Evolution of dioecy in flowering plants. Annu. Rev. Ecol. Syst. 11:15-39

Bellamy, A., Vedel, F. and Bannerot, H.,
(1996). Varietal identification in cichorium inybus $\mathrm{L}$. and determination of genetic purity of F1 hybrid seed sample, basedon RAPD markers. Plant Breeding, 115 (2):128-132.

Bhatnagar.R. Patel.J.C., Shukla.Y.M and Talati.J.G., (1998), Chemical Composition of Simarouba glauca seed. Indian J. Agric. Biochem. 11 (2): 58-59 Biffi,R.,Restivo,F.M.,Tassi,F.,Caporali,E.,C arboni,A.,Marziani-

Longo,G.P.,Spada,A, and

Falavigna,A.,(1995), A restriction fragment lenth polymorphism probe for early diagnosis of gender in Asparagus officinalis L.,Hort.Sci.,30(7):14631464.

Boituex, L.S.Fonseca, M.E.N.and Simon, P.W, (1999), Effects of plant tissue and purifification method on random amplified polymorphic DNA -based genetic fingerprinting analysis in carrot.J.Amer.soc.Hort.sci，124(1); 3238.

Bolano.S. Cottone.C. Viscardi.M. DApice.L. Spigno.P. Rosa.G.D., Capparelli.R. Iannelli.D. Noriello. C., DE, R.G., (1995). Characterization of tomato lines using RAPD - PCR and Flowcylometry Annali-della-Facolta-diScienze-Agrarie-della Universita-deglistudi-d;-Napoli,-Portici, 29:68-83.

Bonosree et.al. (1978) Carcinoma of Oesophagus in Northern Karnataka, Ind.Jour.Cancer, 15, 32.

Botstein D., White R.L., Skolnick M., and Davis R.W. (1980).Construction of a genetic linkage map in man using restriction fragment length polymorphisms. Am.J.Hum, Genet. 32:314-331.

Bracale, M., Caporali, E., Galli,M.G., Longo. C., Marziani-Longo, G.P., Possi, G., Spada, A., Soave, C., Falavigna, A.,Restivo,F.M.and Tassi, F., Raffadi, F., Maestri, E.,(1991),Sex 
determination and differentiation in Asparagus officinalis L. Plant Sci.,80:67-77.

Bradeen. J.M. and Harvey.M.J., (1995), Randomly amplified polymorphic DNA in bulb Onion and its use to asses inbred integrity. J. amer. Soc.hort.Sci, 120 (5):752-758.

Broun, P., and Tanksley, S.D. (1996). Characterization and genetic mapping of simple sequences in the tomato genome.Mol.Genet.250:29-49.

Bruford, M.W., and Wyne, R.K., (1993).Microsatellites and their application to population genetic studies.Curr.Opin.Genet.Dev. 3:939943.

Brunella Martire Bowditch,Darrilyn Albright G, John G.K.Williams, and Michael J.Braun,Use of Randomly Amplified Polymorphic DNA Markers in Comparative Genome Studies, Methods in enzymology,224,p 294.(1991).

Buteler, A.I.; Jarret R.L. and LaBonte, D.R. (1999) Sequence characterization of microsatellites in diploid and polyploidy Ipomoea. Theor. Appl. Genet., 99:123-132.

CaetanoAnolles, G., Bassam, G.J., and Gresshoff, P.M. (1991).High resolution DNA amplification fingerprinting using very short arbitrary oligonucleotide primers.Bio/Technol.9:553-556.

Campbell RJ (1992) (Ed) A Guide to Mangos in Florida. Fairchild Everbest Printing Co. Ltd. Hong Kong Carlson JE, Tulsieram LK, Glaubitz, Luk VWK, Kauffeldt C, Rut-ledge R (1991) Segregation fo random amplified DNA markers in F1 progeny of conifers. Theor Appl Genet 83: 194-200.

Carlquist, S., (1966), the biota of long distance dispersal.iv Genetic systems in the flora of oceanic islands.Evolution, 20:433-455.
Chalmers KJ Waugh R, Sprent JI, Simons AJ, Powell W (1992) De-tection of genetic variation between and within populations of Gliricidia sepium and G. maculata using RAPD markers. Heredity 69: 465-472.

Chao S., Sharp P.J., Worland A.J., Warham, E.J., Koebner, R.M.D., and Gale M.D. (1989).RFLP based genetic maps of wheat homeologous group 7 chromosomes.Theor.Appl.Genet.78:495 -504 .

Chaves, A.L, Vergara, C.E, and Mayer, J.E, (1995), Dicholoromathane as an economic alternative to chloroform in the extraction of the DNA from plant tissues.Plant. Bio.Rep. 13; 18-25.

Cheng.F.S., Weeden.N.F., and Brown.S.K., (1996). Identification of Codominant RAPD markers tightly linked to fruit skin colour in apple. Theor. Appl. Genet., 93 (1-2): 222-227.

Chengyin, L., Weihua, L., Mingjum, L. (1992).Relationship between the evolutionary relatives and the variation of esterase isozymes in tea plant.J.Tea Sci.12:15-20.

Cronquist, A., (1988), The evolution and classification of flowering plants.New York Botanical Gardens, Bronx, NY.

Crooijmans, R.P.M.A., Vanoers, P.A.M, Strijk, J.A., Vanderpoel, J.J., and Groenen, M.A.M (1996).Preleminary linkage map of the chicken $(\mathrm{Ga}$.

Cullis,C.A.,Gorman,M.B.,Bader,J.,Alldridg e,N., and Alldridge,N.,and Alldridge,K.J.(1990).RFLP mapping in flax with particular reference to isolation of flax rust resistance genes.J.Cell Biol.14E,315.

Degani C, EI-Batsri R, Gazit S (1990) Enzyme polymorphism in mango. J. Am Soc Hortic Sci 115: 844-847.

Doyle JJ, JL (1990) Isolation of plant DNA from fresh tissu. From 12:13-15.

Echt CS, Erdahl LA, McCoy TJ (1992) 
Genetic segregation of Random amplified polymorphic DNA in diploid cultivated alfaith Genome 35: 84-87.

Knight RJ, Schnell RJ (1993) Mango (Mangifera indica L) duction and evaluation in Florida and its impact on the word dustry. Acta Hortic 341: 125132.

Kostermans AJGH, Bompard JM (1993) The Mangoes. Press. London.

Penner GA, Bush A, Wise R, Kim W, Domier L, Kasha K, A, Scoles G, Molnar SJ, Fedak G ( 1993) Reproducibility of dom amplified polymorphic DNA (RAPD) analysis among boratories. PCR Methods Applic 2: 341-345.

Ravindran,S.;Rao,A.A.;Naik,V.G.;Tikader, A.; Mukherjee,P. and Thangavelu, K.(1997)Distribution and variation in mulberry germplasm. Indian J.Plant Genet. Resour., 10(2):233-242.

Riedy MF, Hamilton WJ III, Aquadro CF (1992) Excess of Rental bands in offspring from known primate pedigrees Using RAPD PCR. Nuclecic Acids Res 20 (4):978.

Sambrook J, Fritsch EF, Maniatis T (1989) Molecular cloning boratory manual. Cold Spring Harbor Laboratory press, Cold Spring Harbor, N.Y. Schnell RJ, Knight RJ (1992) Frequency of zygotic seedlings from five polyembryonic mango rootstocks. HortScience 27: 174-176.
Schnell RJ, Knight RJ, (1993) Genetic relationships among Mango era spp. Based on RAPD markers. Acta Hortic 341: 86-92.

Sharma,A.;Sharma,R. and Machii,H.(2000) Assessment of genetic diversity in a Morus germplasm collection using fluorescence -based AFLP markers.Theor.Appl.Genet.,101(7):104 9-1055.

Sokal RR, Michener CD (1958). A statistical method for evaluation systematic relationships. Univ Kan Sci Bull 38:1409-1438.

Welsh J, Honeycutt RJ, McClelland M,Sobral BWS (1991) age deteminataion in maize hybrids isomg the arbotrtpry polymerase chain rection ( AP-PCR). Theor Appl Genet 473476.

Welsh J. McClelland M (1990) Fingerprinting genomes using PCR with arbitrary primers Nucleic Acids Res 18; 7213-7218.

Wilde J, Waugh R, Powell W (1992) Genetic fingerprinting of their broma clones using randomly amplified polymorphic DNA ers. Theor Appl Genet 83: 871-877.

Williams JGK, Kubelik AR, Livak KJ, Rafalski JA, Tingey ( 1990) DNA Polymorphisms amplified by arbitrary primiers useful as genetic markers. Nucleic Acids Res. 18: 6531-6535.

\section{How to cite this article:}

Pruthvish, R., and Chikkaswamy, B.K.2016. Genetic Diversity and Relationships among Mango Varieties using RAPD Molecular Markers. Int.J.Curr.Microbiol.App.Sci. 5(1): 778-787 hittp://dx.doi.org/10.20546/ijcmas.2016.501.079 